\title{
Impact of Musculoskeletal Injury in Students of Police Academy a Cohort Study
}

Luiz Fernando de Lima Paulo1,4,6, Claudia de Oliveira Ayala2,6, Vinícius Barroso Hirota ${ }^{3,6}$, Laércio da Silva Paiva ${ }^{1,4}$, Luiz Vinicius de Alcantara Sousa1,4, Francisco Winter dos Santos Figueiredo ${ }^{1,4}$, Italla Maria Pinheiro Bezerra', Luiz Carlos de Abreu1,6, Fernando Adami ${ }^{1,4,5}$

\section{Abstract}

Question: Officers working in operating activities (in the streets) are more exposed to injury when compared to officers who perform non-operational activities (administration or civilians)?

Design: Prospective cohort study.

Participants: Two hundred and twenty cadets of the Police Academy.

Intervention: The officers were separated into an exposed group called the operational (activities in the streets) and other not exposed group called not operational (administration or civilians). Both were followed for one year.

Outcome measures: Several risk factors for the appearance of lesions were collected, among them, the anthropometric data, aerobic strength and individual history. Several risk factors for the appearance of lesions were collected, among them, the anthropometric data, aerobic strength and individual history. The individual history through a self-administered questionnaire, the aerobic through the cooper test resistance and anthropometric data through cutaneous folds and body mass index.

Results: Perform operating activities is not a risk factor for injuries in police. Factors such as aerobic endurance $(p=0.894)$ and being overweight ( $p=0.165)$ are not associated with the emergence of inju-
1 Faculdade de Medicina do ABC. Laboratório de Epidemiologia e Análise de Dados, Departamento de Saúde da Coletividade. Santo André, SP, Brasil.

2 Instituto de Ensino e Pesquisa Médica (IPEMED). Departamento de Microbiologia e Imunologia. São Paulo. SP, Brasil.

3 Universidade Presbiteriana Mackenzie. Departamento de Educação Física e Esporte. São Paulo, SP, Brasil.

4 Instituto Brasileiro de Ensino e Pesquisa Aplicada - IBESPA.

5 Universidade do Extremo Sul Catarinense (Unesc), Criciúma, Santa Catarina, Brasil.

6 Faculdade Nossa Cidade, Carapicuíba, São Paulo, Brasil.

\section{Contact information:}

Luiz Fernando de Lima Paulo. Saúde da Coletividade, Faculdade de Medicina do ABC. Brasil.

Address: Laboratório de Epidemiologia e Análise de Dados, Departamento de Saúde da Coletividade. Av. Príncipe de Gales, 821, Príncipe de Gales, CEP: 09060-650, Santo André, SP, Brasil.

”proflimapaulo@gmail.com 
ries in police. Age and working time the police are factors associated with the onset of injury. The incidence of injury was $20.2 \%$, consistent with findings in the literature.

Conclusion: The work is the first cohort of Brazil with police. The location of the lesions and the incidence are consistent with international results. The officers working on the streets have no more injuries compared those working in administrative functions or are civilians. There need to control the training loads.

\section{Keywords}

Injury; Police; Incidence.

\section{Introduction}

In Brazil, studies in healthcare involving military police officers are extremely scarce, and the research that gives views to the work of the military police are restricted in most cases to the police academies, and emphasize, mainly technical aspects of the profession, illustrating shortcoming on studies on the health of such employees. [1]

The execution of the military police job is characterized by repetitive and uncertain activities that blend paradoxically in daily ostensible policing [1] and exposes its components to specific risks, increasing the likelihood of fractures, dislocations, sprains and injuries. [2]

The large number of military injuries is the major cause of absence from professional activities, thus requiring, strategies for injury prevention. [3] Studies show that lesions present high incidence in military US Navy, [4] represent huge losses to the daily training of the armed forces of Norway and Denmark $[5,6]$ and are the cause of $80 \%$ of cases of interruption of military service of the Defence Forces of Finland [7]. In the Military Police of São Paulo, injuries and pains away the men from the police of work activities and cause reduction in the number of professionals exercising operational policing, preventive and ostensible. $[8,9,10]$

Some factors may influence the appearance of lesions. During the vocational training period for offi- cer, the official students, and united order activities, physical education and various disciplines aimed at police, legal and administrative area, develop extracurricular activities, such as participation in the so called unions, which will address issues related to police or sports activity.

Students the Police Academy Officials of Barro Branco Military (PAOBBM) participate effectively in at least 300 hours class United Order, [11] in addition to continuing long hours sitting in the classroom, [12] which is associated with a significant percentage of students above normal weight standards. [13]

Factors such as anthropometric and physical fitness contribute to the emergence of injuries and pains, especially in the lumbar region. [6] Besides the obesity is a risk factor for heart disease, excess body weight also increases the strain on many joints in the body, including the back, hips, knees, ankles and feet. Thus, the excessive weight can also hinder the maintenance of proper posture with adverse implications on other parts of the body. [14, 15]

Therefore, given the dearth of research on the topic and the need for an analysis of the influence of the activities carried out during the training period on the incidence of injuries, this study aims to verify the incidence of musculoskeletal injuries in Military Police and consider whether if there is a relationship between performance of operational and adminis- 
trative functions in triggering injuries, and analyzing other aspects such as the anthropometric profile, physical fitness, working time in the institution and age, relating them with the appearance of new injuries over the training course for officers.

\section{Methods}

\section{Design}

This is a prospective cohort study [16] from January to December of 2014.

\section{Participants and centres}

We evaluated 220 students ( $n$ : 220) from the Police Academy Officials of Barro Branco Military (PAOBBM), located in São Paulo, Brazil. The study was approved by the Research Ethics Committee of the Faculty of Medicine of $A B C$, under number CAAE: 25030814.5.0000.0082, 516.368.

The Police Academy Officials of Barro Branco Military (PAOBBM) is an Agency for Support and Higher Education (ASHE) of the Military Police of São Paulo state responsible for formation planning and training of officials, under the education law, education decree and general guideline of teaching, according to art. 1 of the Internal Rules of the PAOBBM (RIAPMBB), [17] in which the graduates police receive the Bachelor of Police Science Security and Public Order [17] and students in Police Sciences are designated by official students.

\section{Intervention}

The population was divided according to the functions they performed before entering the PAOBBM in operational and non-operational group.

The operational police is the one who fulfills its functions in ostensible policing, which is exercised by uniformed police, in public places, with preventive nature, by observation and inspection, with vigilance, trying to restrain the action of offenders and prevent the occurrence of criminal acts. [1]
The police not operational in this study, is the one who performs its functions duly uniformed or not, inside the headquarters, exercising administrative activities [1], as well as civilians who entered the PAOBBM.

\section{Outcome measures}

The month of January of 2014, the official students who began the course of Bachelor in Police Sciences have been properly assessed by collecting anthropometric data, physical fitness test and anamnesis. Anthropometric data were collected using a digital scale G-life, model CA8000. Height was collected using a stadiometer approved by Inmetro located in the School of Physical Education of the State Military Police of Sao Paulo.

The general characteristics of the sample were collected using a self-report questionnaire, where the official students mentioned the the presence of injuries and their characteristics, and information on the activities they performed before entry in PAOBBM.

Students who had lesions complaint within 90 days preceding the date of collection were excluded.

The control of the injuries was facilitated by the routine of official students at the PAOBBM. Officials students are subjected to boarding school regime, [17] beyond the rules imposed by the military regime, as must wake at 06:00 a.m. and rest at 22:00 p.m., except the official students responsible for the physical security of the installations.

The appearance of lesions over the year, and their characteristics were checked daily by researchers. To reduce the risk of information bias, an internal routine has been established in the PAOBBM. All the official students who went to medical were properly cataloged on the database, since after medical care, presented its report to the medical diagnosis the official student responsible for the physical safety of installations, which immediately executed the release of information 
in the database. The established routine enabled the effective control of all research participants including on weekends and spare time, considering that there was the presence of official students scaled on site.

The classification of levels of Body Mass Index (BMI) followed the guidelines established by the World Health Organization (WHO). [17] The test used to measure the aerobic endurance was the 12 minute, [18] performed on a runway of 400 meters [19] located in the PAOBBM. The evaluated roamed the maximum distance in a period of 12 minutes. The appropriate classification for aerobic endurance was defined when men officers students reached at least 2000 meters in 12 minutes and women official students the minimum distance of 1590 meters in 12 minutes of running. Values below were classified as inadequate.

\section{Data analysis}

The qualitative variables were presented as absolute and relative frequency, and quantitative by medians and 25 and 75 percentiles, respectively. To analyze the association between the appearance of injuries and characteristics of the studied police, we used the Chi-Square Test and to analyze differences in age and length of service between groups, MannWhitney test due to non-normality of the data (Shapiro-Wilk Test, $\mathrm{p} \leq 0.05$ ). The significance level was $95 \%$. The software used was Stata 11.0 for Windows.

\section{Results}

The general characterization of the sample demonstrates that the official students who enter PAOBBM has, mostly, the origin of the institution itself, i.e., they fulfilled functions of squares in the military police and were approved in the public contest for the APMBB, by a large percentage police who performed operational functions (ostensible policing) (table 1).
Table 1. Characterization of the operational and non-operational military police, São Paulo, Brazil, in 2014.

\begin{tabular}{|c|c|c|}
\hline Characteristics & $\mathbf{n}$ & $\%$ \\
\hline \multicolumn{3}{|l|}{ Group } \\
\hline Non-operacional & 102 & 48.8 \\
\hline Operacional & 107 & 51.2 \\
\hline \multicolumn{3}{|l|}{ Sex } \\
\hline Male & 187 & 87 \\
\hline Female & 28 & 13 \\
\hline \multicolumn{3}{|l|}{ Race } \\
\hline White & 3 & 1.4 \\
\hline Brown & 164 & 75.2 \\
\hline Black & 42 & 19.3 \\
\hline Yellow & 6 & 2.7 \\
\hline Indigenous & 3 & 1.4 \\
\hline \multicolumn{3}{|l|}{ Medication } \\
\hline No & 172 & 78.9 \\
\hline Yes & 46 & 21.1 \\
\hline \multicolumn{3}{|l|}{ Smoke } \\
\hline No & 215 & 98.6 \\
\hline \multirow[t]{2}{*}{ Yes } & 3 & 1.4 \\
\hline & Median & $(p .25-p .75)$ \\
\hline Age & 25 & $(21-28)$ \\
\hline Service Time & 32 & $(0-72)$ \\
\hline
\end{tabular}

Approval in public tender for the PAOBBM, the squares occurs, on median, after 32 months of formed as square, ranging up to 72 months (table 1).

There is a predominance of browns (75.2\%) and blacks (19.3\%) among the official students who entered in PAOBBM in 2014, according in table 1.

The official percentage of students who were injured during the study was $20.6 \%$, and $16.7 \%$ had operational functions before joining the PAOBBM and $20.6 \%$ did not have operational functions, according in table 2. 
Table 1. Incidence of injuries of the second group, sex, BMI categories and endurance in operational and non-operational military police, São Paulo, Brazil, in 2014.

\begin{tabular}{|c|c|c|c|}
\hline \multirow{2}{*}{ Characteristics } & No Injury & With Injury & \multirow{2}{*}{$p^{*}$} \\
\hline & $174(79.8 \%)$ & $44(20.2 \%)$ & \\
\hline \multicolumn{4}{|l|}{ Group } \\
\hline Non-operacional & $85(83.3)$ & $17(16.7)$ & \multirow{2}{*}{0.470} \\
\hline Operacional & $85(79.4)$ & $22(20.6)$ & \\
\hline \multicolumn{4}{|l|}{ Sex } \\
\hline Male & $150(80.2)$ & $37(19.8)$ & \multirow{2}{*}{0.524} \\
\hline Female & $21(75.0)$ & $7(25.0)$ & \\
\hline \multicolumn{4}{|l|}{ BMI } \\
\hline Low weight & $8(72.7)$ & $3(27.3)$ & \multirow{3}{*}{0.165} \\
\hline Normal & $95(84.8)$ & $17(15.2)$ & \\
\hline Overweight & $71(74.7)$ & $24(25.3)$ & \\
\hline \multicolumn{4}{|l|}{ Aerobic endurance } \\
\hline Inappropriate & $7(77.8)$ & $2(22.2)$ & \multirow{2}{*}{0.894} \\
\hline \multirow[t]{2}{*}{ Proper } & $164(79.6)$ & $42(20.4)$ & \\
\hline & $\begin{array}{c}\text { Median } \\
(p .25-p .75)\end{array}$ & $\begin{array}{c}\text { Median } \\
(\mathrm{p} .25-\mathrm{p} .75)\end{array}$ & \\
\hline Age & $21.5(20-25)$ & $27(24-30)$ & $<0.001$ \\
\hline Service Time & $0(0-16)$ & $53(36-96)$ & $<0.001$ \\
\hline Mann-Whitne & $\begin{array}{l}\text { uare test for } \\
\text { or quantitative } \\
\text { Percentil }\end{array}$ & $\begin{array}{l}\text { qualitative varia } \\
\text { e variables. p. } 2 \\
25 \text { and } 75 \text {, res }\end{array}$ & $\begin{array}{l}\text { ables and } \\
5-\text { p.75: } \\
\text { pectively. }\end{array}$ \\
\hline
\end{tabular}

The BMI and adequate aerobic endurance does not significantly contribute to the appearance of lesions ( $p=0.165$ ). Meanwhile, the age and working time in military police are factors associated to lesions ( $p=0.001$ ), regardless of the function performed both before entering PAOBBM (table 2).

There are three main points of musculoskeletal injuries found on police who performed operational functions were: knee and calf (18.2\%), quadriceps (15.1\%) and shoulder, biceps and tibia (9.1\%), according in table 3.

Those who performed administrative duties or were not military before entering the PAOBBM presented mainly musculoskeletal injuries in the knee and calf (20.4\%), tibia and biceps (11.4\%), shoulder (9\%) (table 3).
The injuries arose mainly during physical education classes, specifically in running $(34.4 \%$ and $37.2 \%)$. Classes of united order triggered a large number of lesions (34.9\% in operational and 7\% in non-operating). The non-operating group injured still significant percentage in sports activities outside school hours (23.3\%) (table 3 ).

Table 3. Characteristics of the injuries by location, causes and treatment of operational and non-operational military police, São Paulo, Brazil, in 2014

\begin{tabular}{|c|c|c|}
\hline \multirow{2}{*}{$\begin{array}{c}\text { Characteristics of } \\
\text { injuries }\end{array}$} & Operacional & Non-operacional \\
\hline & $\mathrm{n}(\%)$ & $\mathrm{n}(\%)$ \\
\hline \multicolumn{3}{|l|}{ Local } \\
\hline knee & $6(18.2)$ & $9(20.4)$ \\
\hline Ankle & $3(9.1)$ & $2(4.5)$ \\
\hline Low back & - & $1(2.3)$ \\
\hline Hip & $1(3.0)$ & $2(4.5)$ \\
\hline Shoulder & $3(9.1)$ & $4(9.0)$ \\
\hline Elbow & $1(3.0)$ & - \\
\hline Calf muscle & $6(18.2)$ & $9(20.4)$ \\
\hline Anterior thigh muscle & $5(15.1)$ & $2(4.5)$ \\
\hline Back thigh muscle & $3(9.1)$ & $5(11.4)$ \\
\hline Lower back muscle & - & $2(4.5)$ \\
\hline Foot & $1(3.0)$ & $1(2.3)$ \\
\hline Cinnamon & $3(9.1)$ & $5(11.4)$ \\
\hline Groin & $1(3.0)$ & $1(2.3)$ \\
\hline Wrist & - & $2(2.3)$ \\
\hline \multicolumn{3}{|l|}{ Cause } \\
\hline Running class & $11(34.4)$ & $16(37.2)$ \\
\hline Sport class & $3(9.4)$ & $8(18.6)$ \\
\hline United order class & $11(34.9)$ & $3(7.0)$ \\
\hline Out of sport class & $3(9.4)$ & $10(23.3)$ \\
\hline Out of Running class & - & $5(11.6)$ \\
\hline Others & $4(11.4)$ & $192.3)$ \\
\hline \multirow{2}{*}{$\begin{array}{c}\text { Characteristics of } \\
\text { injuries }\end{array}$} & Operacional & Non-operacional \\
\hline & $\mathrm{n}(\%)$ & $\mathrm{n}(\%)$ \\
\hline $\begin{array}{l}\text { Anti-inflammatory } \\
\text { drugs }\end{array}$ & $9(60.0)$ & $13(60.0)$ \\
\hline Physiotherapy & $5(33.4)$ & $9(40.0)$ \\
\hline Others & $1(6.6)$ & - \\
\hline
\end{tabular}


Figure 1: Distribution of types of injuries in operational military police $(A)$ and non-operating (B), São Paulo, Brazil, 2015.

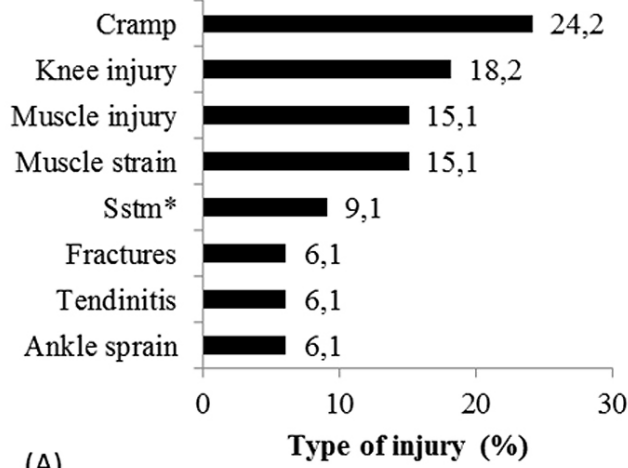

(A)

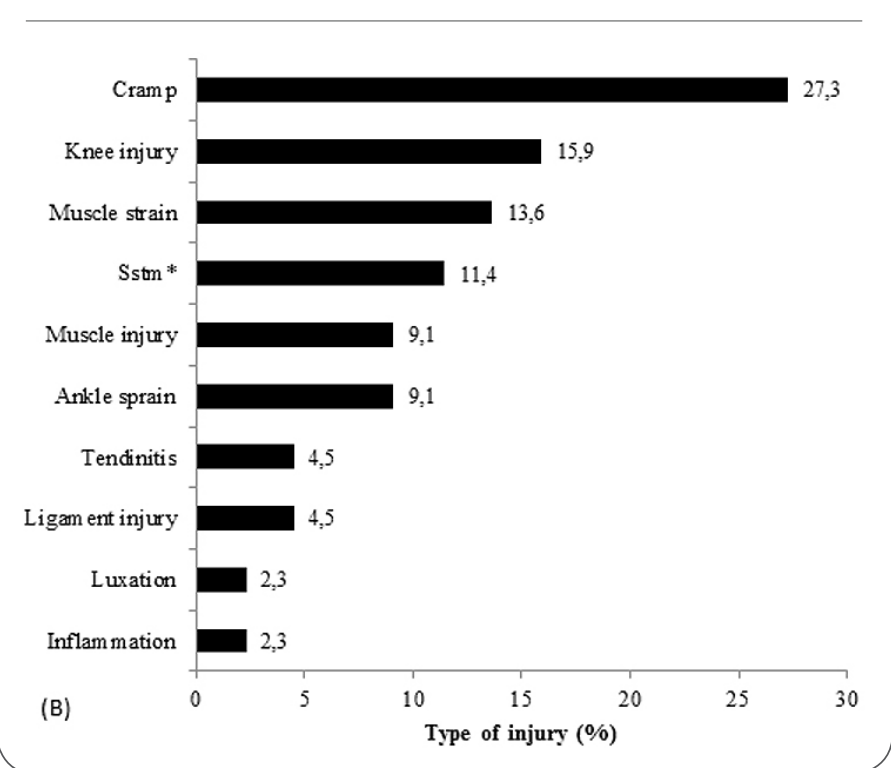

The figure 1 shows the graphical representation of lesions in both groups.

The injuries were present throughout the year, however, in May, September and November in both groups, there is a greater amount of damage, according figure 2 .

\section{Discussion}

The Academy of Barro Branco Military Police (PAOBBM) is responsible for the training of officers of the Military Police of São Paulo [3]. Therefore, they are considered Official: $2^{\circ}$ Lieutenant, $1^{\circ}$ Lieutenant, Captain, Major, Lieutenant Colonel and finally, Colonel. Soldiers, Cables, Sergeants and Sub-Lieutenants are consider squares of the Military Police, in turn, annually join the PAOBBM to amount the career.

In recent years, the number of squares that enter into the PAOBBM is increasing (61\% in 2014); from most diverse areas of expertise (administrative and operational) however, characterized the squares with little service time in the institution.

Thus, many squares that made their functions in operational and administrative activities at the Military Police enter into the PAOBBM as well as civilians and members of other institutions such as

Figure 2: Distribution of number of new cases of injuries per month in operational and non-operational military police, São Paulo, Brazil, in 2015.

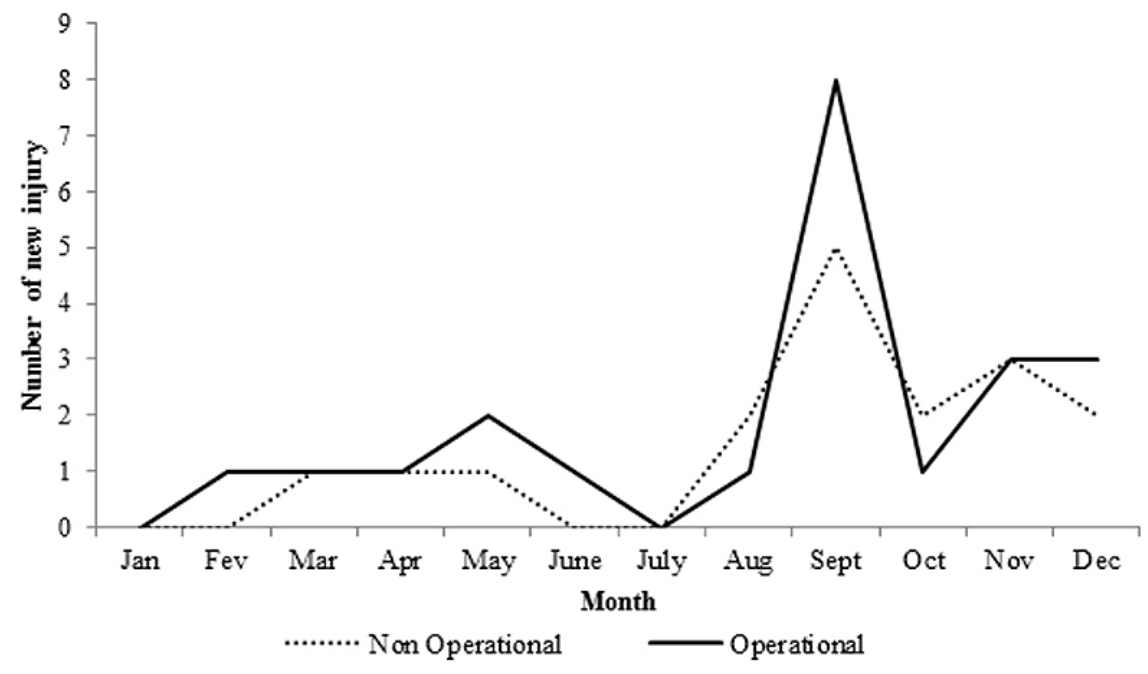


the Armed Forces (Army, Navy and Air Force), the Municipal Guards and Prison agents.

The job of military officers who carry out their operationally duties, takes on very particular characteristics: they have no scheduled times, mainly for the end of the service, i.e., it does not have a fixed journey, like other workers.

The police officers who carry out their duties with the management have fixed schedules, work from Monday to Friday and specifically in the Military Police of São Paulo, and exercises themselves physically twice a week.

The official student's percentage who were injured over the year of 2014 (20.2\%) shows similarity with the results obtained in other studies.

In a study by the US Air Force, the incidence of injury among military ranged from $20 \%$ to $30 \%$, $[24,25]$ data similar to that found in this study.

On the other hand, the injury percentage found was much lower, with a percentage of $11 \%$ in the U.S. Army, $9 \%$ in the Navy military and $8 \%$ in military US Air Force. [24, 25]

By the features presented in the studies, [21, 22] it appears that the military population analyzed was the operational groups, or susceptible to the enormous amount of training equipment damage and overload. [22]

The data analysis showed that, unlike those found in studies with military armed forces, [21, 22, 23, 24, 25] official students of the Military Police of São Paulo, there was no significant difference ( $p$ $=0.470$ ) for the emergence of injury and the job function (operational or administrative) in the period before the entry into PAOBBM, i.e., the performance of operating activities in the period prior to entry into APMBB not shown to be a risk factor for injuries trigger along the course.

Allied to this, the huge difference between the administrative and operational functions do not influence the appearance of lesions. Even before the huge level of stress and overload equipment, [12] operational police do not have higher risk of deve- loping musculoskeletal injuries compared to those who perform administrative functions.

Other research with military show that low physical fitness and high BMI are associated with the appearance of lesions, [12, 25] however, in this stu$d y$, there was no significant difference for low aerobic endurance and the appearance of lesions ( $p$ $=0.894$ ).

Therefore, it is seen that the development of injuries, gender $(p=0.524), B M I(p=0.165)$ and endurance $(p=0.894)$ are not directly related to the appearance of lesions throughout the period of training, independent function performed before the entry period in PAOBBM (operating or non-operating). Only the age and length of service showed significance for the appearance of lesions $(p<0.001)$, a factor physiologically normal for all professions, with a bow as research, progressively. [12]

Some studies show that in other military forces, there is a huge number of injuries during the military training, namely activities operationalize [21] and runnings. [23-25]

Officials students developed the lesions mainly in the lower limbs (quadriceps, knee, calf, tibia) and upper limb (shoulder), classifying the cause of injury to factors such as race and sports activities outside school hours, which is similar to that seen in other studies [23-25] as to the wound locations in the military.

However, differ as a percentage of $9 \%$ of lesions in the upper limbs. International studies show that injuries in the upper limbs are little incidents military, [24] with a percentage on average of 3\%.

Musculoskeletal injuries became pretty present, a percentage that does not diverge from international research. $[20,21]$ In a survey of the U.S. military, it was found that the greatest amount of damage occurred in the musculature of the lower limbs, with a percentage of $14 \%$. However, it is important that the analyzed group was in combat in the Persian Gulf War and in Bosnia, i.e., exercising real and extremely stressful functions. [21, 22] 
Studies show that type and amount of training are responsible for the appearance of lesions. [12, 23] In PAOBBM, physical education classes have ninety minutes duration, which often based on races in groups and long term, demonstrating non-compliance with the principles of sports training.

The training volume is extremely high in some specific months like January, May, September and December, these months that have different internal and external enactments, which, as shown in Figure 2, increase the number of official students with injuries, regardless the function exercised before entering the PAOBBM.

Likewise, the international studies, $[22,27]$ the appearance of lesions in the initial weeks of training are extremely common; [22] however, to fit a significant reduction in the volume of training is necessary, since the distances and the long period running are associations for the appearance of lesions. [27, 28]

It highlights the importance of deepening the theme in question conducting research involving health care considering the diagnosis, treatment, and prevention of diseases, accidents, and other physical and/or mental disabilities [29, 30]

\section{Conclusions}

It was verified that the incidence of injury in official students is not associated with physical factors such as BMI and aerobic endurance. There is a close relationship between the onset of injuries, age and length of service at the military police.

The growing number of injuries in specific months reflects excessive training volume throughout the training period, especially in months with military events.

These results point to the need for improvement in the physical training of military police officers taking into account aspects related to the history of time at the Military Institution and the work routine.

\section{Ethics approval}

The Ethics Committee(s) of Faculty of Medicine of $A B C$ approved this study, under number CAAE: 25030814.5.0000.0082, 516.368. All participants gave written informed consent before data collection began.

\section{Competing interests}

None.

\section{Source(s) of support}

None.

\section{Acknowledgements}

None.

\section{References}

1. Fraga CK. Peculiarities of military police work. Virtual journal texts and contexts, v.6, p.1-19, dezembro, 2006.

2. Teodoro HC. Prevalence of Musculoskeletal Injuries in Military Physical Training of the 63rd Infantry Battalion of Tubarão/SC.v Final Work of Physiotherapy Course University of Southern of Santa Catarina, Tubarão, 2007.

3. Committee on Trauma Research, Commission of the Life Sciences, National Research Council, and the Institute of Medicine. Injury in America: a continuing health problem. Washington, DC: National Academy Press, 1985.

4. Evans GWL. Stress fractures at Commando Training Centre Royal Marines, Lympstone: a retrospective survey. J. R. Navy Med. Serv. v.68, p.77-81, 1982.

5. Rosendal L, Langberg $H$, Skov-Jensen A, Kjaer M. Incidence of injury and physical performance adaptations during military training. Clinic Journal Sport Medicine, v.13,157-63, 2003.

6. Heir T, Glomsaker P. Epidemiology of musculoskeletal injuries among Norwegian conscripts undergoing basic military training. Scand Journal Medicine Science Sports, v.6, n.3, p. 186-91, 1996.

7. Taanila H, Suni J, Pihlajamaki $H$, Mattila VM, Ohrankammen $O$, Vuorinen P, Parkkari J. Musculoskeletal disorders in physically active conscripts: a one-year follow-up study in the Finnish Defence Forces. BioMed Central, v.10, n.10, p.89-97, 2009.

8. Rosa FAS, Paulo LFL, Oliveira JA, Ayala CO. The gymnastics as LER/DORT reduction factor in the Military Police Rounds Chichi with Motorcycles. Enaf Science Journal, v.7, n.1, p. 152-163, 2012. 
9. Hirota, VB, França, E, Paulo, LF.L, Ayala, CO. Adami, F. Goal's Orientation of Brazilian's Military Police Cadets. Sch. J. Arts. Humanit. Soc. Sci. 2014; 2(5C):779-781.

10. Paulo, L.F.L. Andrade, M.F.A.M. Neto, C.B. Hirota, V.B. Adami, F. Prevalência de dor em alunos da academia de polícia militar do barro branco. Revista ENAF Science | Volume 9 - N 01-1 Semestre de 2014

11. Polícia Militar do Estado de São Paulo. Grade curricular do Curso de Bacharel em Ciências Policiais de Segurança e Ordem Pública da Academia de Polícia Militar do Barro Branco. São Paulo, 2013.

12. Paulo LFL, Bordim Neto C, Andrade MFAM, Hirota VB, Adami F. Pain prevalence in students the Barro Branco Military Police Academy. Revista Enaf Science, v.9, p.20-27, 2014.

13. Mantovane LL, Bordim Neto C, Dejane T. Paulo LFL. Analysis of anthropometric and physical capabilities of military police. Enaf Science Journal, v.8, n.2, p.19-26, junho agosto, 2013.

14. Rio RP. LER: science and law- new health horizons at work. $1^{\text {a }}$ edição. Belo Horizonte: Health, 1998.

15. Lopes, AD, Costa LO, Saragiotto BT, Yamato TP, Adami F, Verhagen E. Musculoskeletal pain is prevalent among recreational runners who are about to compete: an observational study of 1049 runners. J. Physiother. 2011;57(3):179-82

16. MALTA, MONICA STROBE Initiative: subsidies for reporting observational studies. Journal of Public Health [online]. v.44, n.3, p. 559-565, 2010.

17. Polícia Militar do Estado de São Paulo. Regimento Interno da Academia de Polícia Militar do Barro Branco. São Paulo, 2010.

18. [WHO] World Health Organization. Obesity: prevening and managing the global epidemic. Report of a WHO Consultation on Obesity. Geneva; 1998.

19. American College Of Sports Medicine. ACSM's Guidelines for the stress tests and their prescription. $6^{\circ} \mathrm{Ed}$. Rio de Janeiro: Guanabara Koogan, 2003.

20. Lei Complementar $n^{\circ}$ 1.036- Lei de ensino da Polícia Militar do Estado de São Paulo. São Paulo. 11 de janeiro, 2008.

21. U.S. Army Center for Health Promotion and Preventive Medicine. Medical Surveillance Monthly Report, November, v.2, p.8-9. Available at: http://amsa.army.mil/msmr/htm.

22. Kaufman KR, Brodine S, Shaffer R. Military training-related injuries: surveillance, research, and prevention. Am J Prev Med v.18, n.3, p.54-63, 2000.

23. Jones $B H$, Cowan DN, Knapik JJ. Exercise, training, and injuries. Sports Med, v.18, p.202-214, 1994.

24. Shaffer RA, Brodine SK, Almeida SA, Ronaghy S. Use of simple measures of physical activity to predict stress fractures in young men undergoing a rigorous physical training program. Am J Epidemio/ v.149, p.236-242, 1999.

25. Jones BH, Cowan DN, Tomlinson JP, Robinson JR, Polly DW, Frykman PN. Epidemiology of injuries associated with physical training among Young men in the Army. Med Sci Sports Exerc, v.25, p.197-203, 1993.
26. Koplan JP, Powell KE, Sikes RK. An epidemiologic study of the benefits and risks of running. JAMA, v.248, p.3118-21, 1982

27. Marti B, Vader JP, Minder CE. On the epidemiology of running injuries- the 1984 Bern Grand Prix Study. Am J Sports Med, v.16, p.285-294, 1988.

28. Pollock ML, Gettman LR, Milesis CA. Effects of frequency and duration of training on attrition and incidence of injuries. Med Sci Sports Exerc, v.9, p.31-36, 1977.

29. Monteiro CBM, Almeida Junior AD, Wajnzstejn R. Project Management in Health and Medical Research. Journal of Human Growth and Development. 2014; 24(3): 239-242. DOI: dx.doi.org/10.7322/jhdg.88895

30. Atrash HK, Carpentier R. The evolving role of public health in the delivery of health care. Rev Journal of Human Growth and Development.. 2012; 22(3): 396-9.

\section{Comment on this article:}

\section{$4(8)$ in $8+\mathbf{S}$}

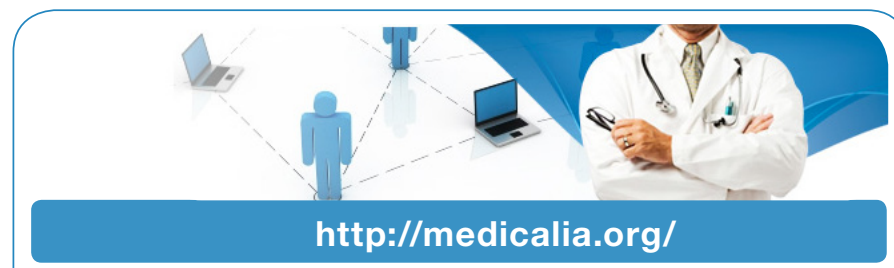

Where Doctors exchange clinical experiences, review their cases and share clinical knowledge. You can also access lots of medical publications for free. Join Now!

\section{Publish with iMedPub}

\section{http://www.imed.pub}

International Archives of Medicine is an open access journal publishing articles encompassing all aspects of medical science and clinical practice. IAM is considered a megajournal with independent sections on all areas of medicine. IAM is a really international journal with authors and board members from all around the world. The journal is widely indexed and classified Q1 in category Medicine. 